\title{
Evaluation of analgesic activity of ethanolic extract of alpinia galanga rhizomes in experimental animal models
}

\author{
Dasari Sriraj, ${ }^{1, *}$, Mohd. Abdul Rauf ${ }^{2}$ \\ ${ }^{1}$ PG Cum Tutor, ${ }^{2}$ Professor, Dept. of Pharmacology, S. Nijalingappa Medical College \& HSK Hospital \& Research Centre Bagalkot, \\ Karnataka, India
}

*Corresponding Author: Dasari Sriraj

Email: drsriraj.dasari@gmail.com

\begin{abstract}
Introduction: Alpinia galanga Linn is a widely used medicinal plant. It is also known as Greater Galangal and belongs to family Zingiberaceae. The plant is a perennial rhizomatous herb and has been claimed to possess analgesic activity apart from many medicinal properties.

Objectives: The aim of the present study was to evaluate the analgesic activity of ethanolic extract of alpinia galanga rhizomes (EEAGR) in experimental animals.

Methods: Acute toxicity test was done following the Organization of Economic Cooperation and Development guidelines.100 mg/kg, 200 $\mathrm{mg} / \mathrm{kg}$, and $400 \mathrm{mg} / \mathrm{kg}$ body weight [b.w] of ethanolic extract of alpinia galanga rhizomes was given orally to experimental animals. EEAGR was evaluated for central analgesic activity by using the tail flick method and peripheral analgesic activity by using the acetic acid induced writhing test using aspirin (300 mg/kg b.w and $100 \mathrm{mg} / \mathrm{kg} \mathrm{b.w} \mathrm{orally)} \mathrm{as} \mathrm{the} \mathrm{standard} \mathrm{drug} \mathrm{respectively.}$

Results: EEAGR at $400 \mathrm{mg} / \mathrm{kg}$ produced highly significant and greater analgesic activity than Aspirin (standard drug) in tail flick method. EEAGR at dose $400 \mathrm{mg} / \mathrm{kg}$ has shown comparable reduction in mean total number of writhings which is equivalent to that of Aspirin (standard drug) in writhing test.

Conclusion: EEAGR has significant central and peripheral analgesic activity.
\end{abstract}

Keywords: Alpinia galanga, Analgesic, Pain, Tail flick, Writhing.

\section{Introduction}

Pain has been officially defined according to International Association for Study of Pain as an unpleasant sensory and emotional experience associated with actual or potential tissue damage. ${ }^{1}$ According to Sherrington pain is the physical adjunct of an imperative protective reflex. Pain differs from other sensations in that pain sounds a warning that something is wrong, preempts other signals and is associated with an unpleasant affect. It turns out to be immensely complex because when pain is prolonged and tissue is damaged, central nociceptor pathways are sensitized and reorganized. ${ }^{2}$ Drugs used for pain relief are NSAIDs, opioid analgesics and co-analgesics such as corticosteroids, neuroleptics, benzodiazepenes, local anaesthetics, capsaicin and clonidine. ${ }^{1}$ Among all, NSAIDs are most widely used with basic mode of action by inhibiting pro-inflammatory enzyme cyclo-oxygenase (COX).They contribute to many side effects ranging from mild gastrointestinal to severe cardiovascular side effects. ${ }^{3}$ Opioid analgesics also can be used in treatment of acute pain as their benefits generally outweigh their few significant risks such as constipation, sedation, nausea, and vomiting, itching and respiratory depression. ${ }^{1}$ Inspite of availability of many medications for management of pain, scope for new drug persists due to adverse effects of the existing drugs.

On the contrary, herbal medicines with good absorption, less toxicity, and easy availability have been used since ancient times. ${ }^{4}$ The plant kingdom provides enormous source of pharmacologically active molecules for new drug discovery. Many medicines which are of plant origin have been used since long time to treat various disorders. Hence it is essential that efforts need to be made to introduce new medicinal plants to develop cheaper, effective and safe analgesic drugs. ${ }^{5}$

Alpinia galanga (Linn.) Willd. belonging to family Zingiberaceae which is a well known plant in India, Sri Lanka, Malaysia, Thailand and Indonesia is one amongst them. ${ }^{6-7}$ It is also known as Greater Galangal. The plant has been extensively used for treatment of various disorders including hypertension, diabetes, rheumatism, as antiulcer, for asthma, immunomodulation, inflammation and as antimicrobial. ${ }^{8-13}$ It is a good natural antioxidant and various researchers have studied the active constituents isolated from A. galanga. ${ }^{8}$ The phytoconstituents which were isolated from the plant were found very useful in different disorders. The plant is used in polyherbal preparations as analgesics which are available over the counter. Only few studies have been done to evaluate the analgesic activity of the plant. The analgesic effects of Alpinia galanga have been studied in rheumatoid conditions. Treatment of pain constitutes significant medical needs because most of the people are affected with this condition than any other disease state. There is need for safe and efficacious drug with better tolerability. Hence an earnest attempt is being made in this study to evaluate the analgesic effect of ethanolic extract of A. galanga rhizomes (EEAGR) in experimental animals.

\section{Materials and Methods}

Plant Material: Rhizomes of Alpinia galanga were collected from Horticulture University of Bagalkot district, Karnataka (Fig. 1) The rhizome identity was authenticated by Botanist Prof. V.P. Singh, Horticulture University, 
Bagalkot. The voucher specimen (010) is kept in the Pharmacology Department at SNMC, Bagalkot.

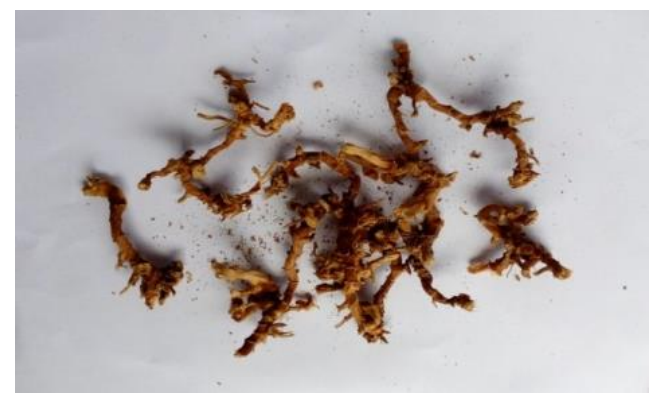

Fig. 1: Dried rhizomes of Alpinia galanga

Drugs and Chemicals: Aspirin (Reckitt Benckiser India Ltd, Mysore), $0.6 \%$ acetic acid (Nice laboratory reagents, Cochin) and normal saline were used in this study.

Instruments: Feeding tube, Insulin syringe, Mouth gags, Tuberculin syringe, Ryle's tube, beaker, glass jar, glass rod, Analgesiometer, Soxhlet apparatus, Digital weighing balance, Stopwatch,.

Preparation of Plant Extract: $80 \%$ ethanol was used for extraction of material using soxhlet extraction apparatus and it was evaporated to dry at $60^{\circ} \mathrm{C}$. 40 grams of crude extract was yielded from 300 grams rhizome powder of Alpinia galanga. The solid residues were stored in airtight container and preserved in the refrigerator at $-20^{\circ} \mathrm{C} .{ }^{14}$ From this stock, fresh preparations were obtained whenever they were required.

Experimental Animals: Animals were procured from the Animal house, S. Nijalingappa Medical College, Bagalkot. Swiss albino mice of either gender weighing 20-30grams and Wistar albino rats of either gender weighing 150-200 grams were selected for the experiment.

Exclusion Criteria: Pregnant animals, animals with an infection, animals with injuries, deformities and animals showing > 20-30 seconds of reaction time in tail flick experiment were excluded from the study.

Housing Conditions: All the animals were maintained under standard animal house conditions at $12: 12 \mathrm{hr}$ dark: light cycle, at temperature $25 \pm 2{ }^{\circ} \mathrm{C}$, humidity $35-60 \%$ and other micro and macro environment conditions as suggested by Committee for the Purpose of Control and Supervision of Experiments on Animals (CPCSEA) prior to and during study. All animals were housed in a polypropylene cage covered with a stainless steel wire mesh and a paddy husk bed, with adequate provision for feed and water and were maintained on standard laboratory diet (VRK Nutritionals, Pune) and water was provided ad libitum. The study was started only after getting the Institutional Animal Ethics Committee approval (IAEC/ S. Nijalingappa Medical College, Bagalkot, Reg No.829/AC/04/CPCSEA).

Phytochemical Screening: The freshly prepared EEAGR was subjected to phytochemical screening tests for detection of various constituents. ${ }^{15-16}$

Acute Toxicity Study: The experimental animals were treated with increasing doses of the extract. The toxicity studies were conducted according to the Organization for Economic co-operation and development (OECD) 423 guidelines ${ }^{17}$ and treated animals were observed for any abnormal or toxic manifestations and mortality.

\section{Evaluation of Analgesic Activity Central Analgesic Activity}

Tail Flick Method: It was carried out in healthy wistar albino rats. 50 wistar albino rats weighing 150-200 grams were randomly divided into five groups of ten rats each after $12 \mathrm{hrs}$ fasting. Group I received $0.5 \mathrm{ml}$ of normal saline which was considered as control group, Group II received $300 \mathrm{mg} / \mathrm{kg}$ b.w of aspirin which was considered as standard group $^{18}$ and Groups III, IV, V received EEAGR which were considered as test groups. All the drugs were administered orally (p.o). During the experiment rat was placed into restrainer, leaving the tail exposed outside the restrainer. Tail was cleaned with the help of cotton soaked in water or ethanol. Rat was allowed to settle down in the restrainer. Restrainer was then placed on the analgesiometer. Tail was held gently and then placed at a short distance above the heated nicrome wire, without the tail directly coming in contact with wire. $1 / 3$ rd tail proximally was left due to the thick keratinized skin. To maintain normal room temperature with rest of the surrounding environment, water flow was continuously maintained within the metal bars surrounding the nichrome wire on the analgesiometer. The rat tried to pull the tail away and this tail flicking was considered as the end point of this test. The time which was taken for tail flick response was measured, recorded and taken as the reaction time and mean time taken for tail flick response of whole group was calculated. Cut off time was kept at 20-30 seconds to avoid any tissue damage. The animals showing reaction time of more than 20-30 seconds were excluded from the study. ${ }^{19}$ Following initial reading the animals received the respective drugs orally and the reaction time was noted for each rat in different groups after $1 / 2 \mathrm{hr}, 1 \mathrm{hr}, 2 \mathrm{hr}$ and $3 \mathrm{hr}$ (Fig. 2).

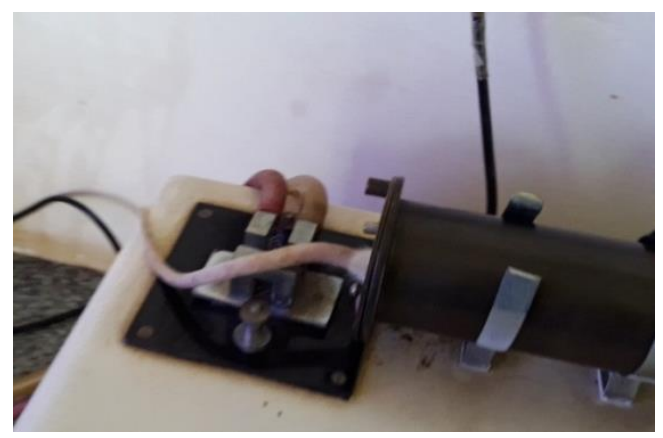

Fig. 2: Rat showing tail flick response

\section{Peripheral Analgesic Activity}

Acetic Acid Induced Writhing Test: 50 healthy swiss albino mice weighing 20-30 grams were randomly divided into five groups of ten mice each after 12 hours of fasting. Group I received $0.5 \mathrm{ml}$ of normal saline which was considered as control group, Group II received $100 \mathrm{mg} / \mathrm{kg}$ 
b.w of aspirin which was considered as standard group. ${ }^{20}$ Group III, IV, V received EEAGR which were considered as test groups. All the drugs were given orally (p.o). $0.6 \%$ $\mathrm{v} / \mathrm{v}$ acetic acid $(10 \mathrm{ml} / \mathrm{kg})$ was used to induce writhing which was prepared by adding $0.6 \mathrm{ml}$ of acetic acid in $100 \mathrm{ml}$ of distilled water. The solution was prepared freshly before each experiment. After 1 hour of administration of standard drug and extract, $1 \mathrm{ml} / 100 \mathrm{gm}$ body weight of $0.6 \%$ acetic acid was given intraperitoneally (i.p) to all the mice to induce pain which was characterized by abdominal constrictions or writhings. Number of writhings were counted between 5 and 20 minutes after acetic acid injection $^{21}$ and the percentage of protection was calculated (Fig. 3).

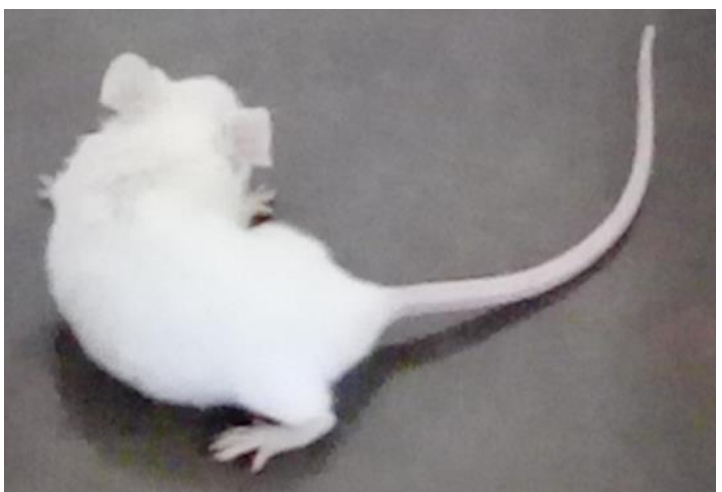

Fig. 3: Mouse showing writhing

\section{Statistical Analysis}

The data obtained from the study was expressed as Mean \pm SEM (standard error of mean) and was statistically analyzed using one way analysis of variance (ANOVA) followed by Dunnett's multiple comparison tests. For all the tests done a ' $p$ ' value of 0.05 or less was considered as significant.

\section{Results and Discussion}

Phytochemical Screening: Various constituents such as alkaloids, carbohydrates, saponins, tannins, protein, glycosides, steroids, terpinoids and flavonoids were revealed.

Acute Oral Toxicity Study: Acute toxicity studies revealed that the extract was safe at all doses when administered orally to rats up to a dose of $2000 \mathrm{mg} / \mathrm{kg}$ and no mortality was observed during the 14 days of the observation period.

Tail flick method (for evaluating central analgesic activity): The results are shown in Table 1 and Graph 1 . EEAGR showed a dose dependent increase in reaction latency to thermal pain. At 1, 2, 3hr the EEAGR at 400 $\mathrm{mg} / \mathrm{kg} \quad$ b.w significantly $\quad(16.37 \pm 0.29, \quad 18.48 \pm 0.13$, $19.42 \pm 0.10 ; \mathrm{p}<0.001)$ evoked a longer reaction latency than Aspirin $(14.07 \pm 0.43,16.44 \pm 0.36,18.95 \pm 0.29)$. Even it prolonged the reaction latency $(\mathrm{p}<0.001)$ at doses $100 \mathrm{mg} / \mathrm{kg}$ b.w after $1 / 2 \mathrm{hr}$ and at dose $200 \mathrm{mg} / \mathrm{kg}$ b.w after $1 / 2 \mathrm{hr}, 1 \mathrm{hr}$ and $2 \mathrm{hr}$ of drug administration. EEAGR at $400 \mathrm{mg} / \mathrm{kg}$ produced highly significant and greater analgesic activity than Aspirin.

Table 1: Reaction time (in seconds) in tail flick method in control, standard and test groups

\begin{tabular}{|l|c|c|c|c|c|}
\hline Group & $\begin{array}{c}\text { Ohr } \\
\mathbf{M} \pm \text { SEM }\end{array}$ & $\begin{array}{c}1 / 2 \mathbf{h r} \\
\mathbf{M} \pm \text { SEM }\end{array}$ & $\begin{array}{c}\mathbf{1 h r} \\
\mathbf{M} \pm \text { SEM }\end{array}$ & $\begin{array}{c}\mathbf{2 h r} \\
\mathbf{M} \pm \text { SEM }\end{array}$ & $\begin{array}{c}\text { 3hr } \\
\mathbf{M} \pm \text { SEM }\end{array}$ \\
\hline $\begin{array}{l}\text { Group I } \\
\text { (Control) }\end{array}$ & $11.14 \pm 0.18$ & $11.02 \pm 0.20$ & $10.97 \pm 0.23$ & $11.04 \pm 0.20$ & $11.06 \pm 0.23$ \\
\hline $\begin{array}{l}\text { Group II } \\
\text { (Aspirin 300mg/kg) }\end{array}$ & $10.69 \pm 0.24$ & $11.42 \pm 0.24$ & $14.07 \pm 0.43$ & $16.44 \pm 0.36$ & $18.95 \pm 0.29$ \\
\hline $\begin{array}{l}\text { Group III } \\
\text { (EEAGR100mg/kg) }\end{array}$ & $11.12 \pm 0.35$ & $12.36 \pm 0.43^{*}$ & $12.96 \pm 0.37$ & $14.39 \pm 0.28$ & $14.93 \pm 0.31$ \\
\hline $\begin{array}{l}\text { Group IV } \\
\text { (EEAGR200mg/kg) }\end{array}$ & $12.26 \pm 0.35$ & $13.42 \pm 0.52^{*}$ & $15.67 \pm 0.38^{*}$ & $17.47 \pm 0.18^{*}$ & $18.20 \pm 0.23$ \\
\hline $\begin{array}{l}\text { Group V } \\
\text { EEAGR400mg/kg) }\end{array}$ & $11.46 \pm 0.33$ & $13.43 \pm 0.36$ & $16.37 \pm 0.29^{*}$ & $18.48 \pm 0.13^{*}$ & $19.42 \pm 0.10^{*}$ \\
\hline F & 3.768 & 8.793 & 37.2888 & 142.591 & 205.852 \\
\hline P & 0.010 & 0.000 & 0.0000 & 0.000 & 0.000 \\
\hline
\end{tabular}

When compared with standard; $* p<0.001$. All the values are expressed as Mean \pm SEM $(n=10)$ 
Graph 1: Reaction time (in seconds) in tail flick method

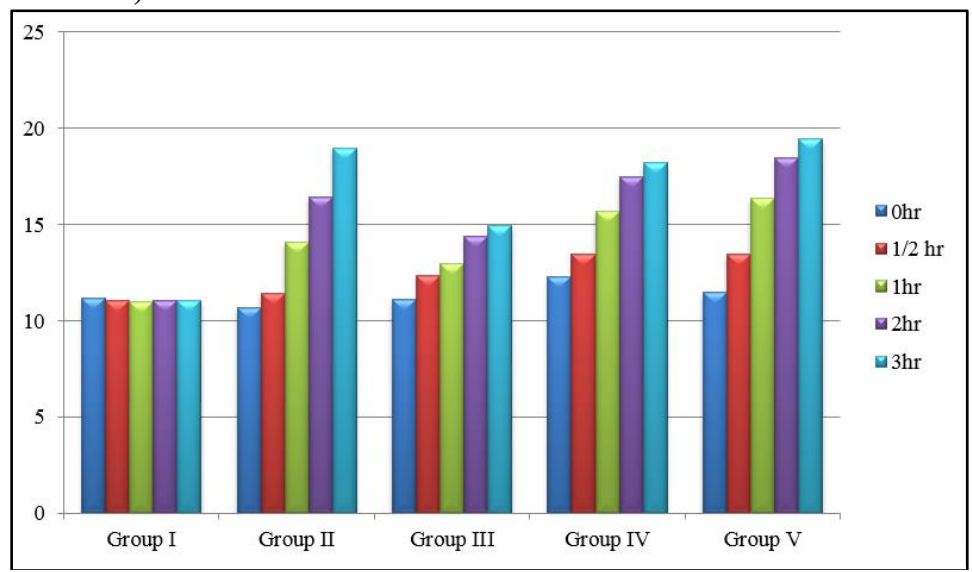

Acetic acid induced writhing test (for evaluating peripheral analgesic activity): The results are shown in Table 2 and Graph 2. EEAGR at dose $400 \mathrm{mg} / \mathrm{kg}$ has shown comparable reduction in mean total number of writhings $(13.10 \pm 0.45)$ which is equivalent to that of standard drug Aspirin $(12.50 \pm 0.34)$. The test extract however in doses of
$100 \mathrm{mg} / \mathrm{kg}$ and $200 \mathrm{mg} / \mathrm{kg}$ were not as efficacious as compared to aspirin. $100 \mathrm{mg} / \mathrm{kg}, 200 \mathrm{mg} / \mathrm{kg}$, and $400 \mathrm{mg} / \mathrm{kg}$ b.w of test drug showed $18.65 \%, 44.02 \%$, and $67.41 \%$ inhibition of writhings in mice compared with control group. Aspirin showed $68.90 \%$ inhibition of writhings.

Table 2: Number of writhings and percentage inhibition (acetic acid induced writhing test)

\begin{tabular}{|l|c|c|}
\hline \multicolumn{1}{|c|}{ Groups } & M \pm SEM & Percentage of Inhibition (\%) \\
\hline Group I (Control) & $40.20 \pm 0.41$ & - \\
\hline Group II(Aspirin $300 \mathrm{mg} / \mathrm{kg}$ ) & $12.50 \pm 0.34$ & 68.90 \\
\hline Group III (EEAGR $100 \mathrm{mg} / \mathrm{kg}$ ) & $32.70 \pm 0.68^{*}$ & 18.65 \\
\hline Group IV(EEAGR $200 \mathrm{mg} / \mathrm{kg}$ ) & $22.50 \pm 0.52^{*}$ & 44.02 \\
\hline Group V(EEAGR $400 \mathrm{mg} / \mathrm{kg}$ ) & $13.10 \pm 0.45^{*}$ & 67.41 \\
\hline
\end{tabular}

$F=596.008$; $P<0.001$ When compared with standard; $* \mathrm{p}<0.001$. All the values are expressed as Mean \pm SEM $(\mathrm{n}=10)$

\section{Graph 2: Showing number of writhings}

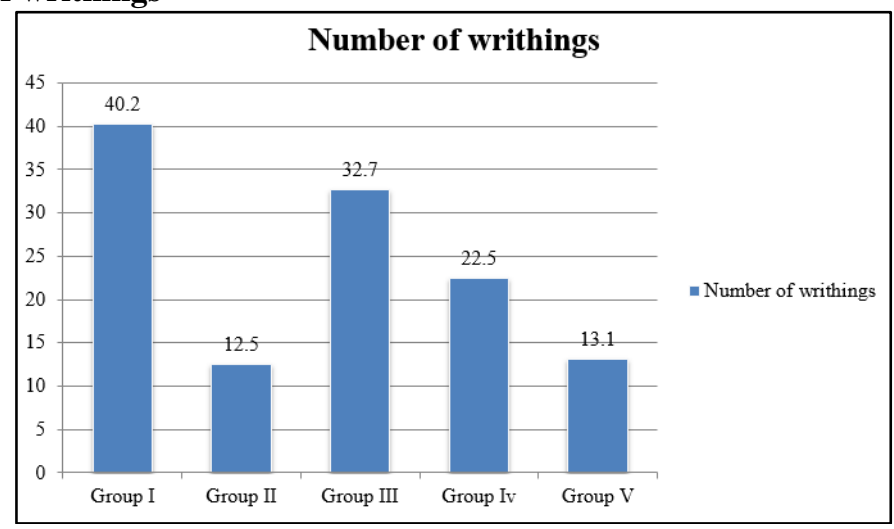

\section{Discussion}

Alpinia galanga (Linn.) Willd. which belongs to Zingiberaceae is a well-known rhizomatous perennial herb in India, Sri Lanka, Indonesia, Thailand and Malaysia. All parts of the plant possess a multitude of phytochemical secondary metabolites. These secondary metabolites impart an unprecedented variety of medicinal uses to the plant. The present study was undertaken to investigate analgesic activity of EEAGR.
Significant analgesic activity of methanolic extract of alpinia galanga rhizomes was seen in previous studies. ${ }^{22-23}$ This study is the first report regarding analgesic activity of ethanolic extract of alpinia galanga rhizomes.

Tail flick method and acetic acid induced writhing test (anti nociceptive models) were used to evaluate central and peripheral analgesic activity of EEAGR. The results from the present study have shown that EEAGR produced significant analgesic activity against thermal and chemical models of nociception in experimental animals (rats and mice). 
Tail flick method is considered as a specific screening method for centrally acting analgesics. The tail flick method which is considered to be a spinal reflex induced by heat according to Schumacher et al. (1940), and Wolff et al. (1940), but could also involve higher neural structures (central analgesic activity). ${ }^{24,25}$ Pain is modulated centrally by a number of complex processes such as opiate, dopaminergic, descending noradrenergic and serotonergic systems. The significant increase in pain threshold produced by the extracts derived from rhizomes of alpinia galanga in tail flick method may be via central mechanisms involving these receptor systems or may be via peripheral mechanisms involved in the inhibition of prostaglandins, leukotrienes and other endogenous substances which are considered as key mediators in pain. ${ }^{26}$

Peripheral analgesic activity of EEAGR was evaluated by using writhing test in mice according to the method of Koster et al. ${ }^{27}$ Acetic acid induced writhing response is used to evaluate peripherally acting analgesics and pain sensation is triggered by local inflammatory response. Intraperitoneal injection of acetic acid produces pain through activation of chemosensitive nociceptors or irritation of the visceral surface, which lead to the liberation of histamine, bradykinin, prostaglandins and serotonin. The extracts derived from rhizomes of alpinia galanga exhibited significant analgesic activity in mice by inhibiting acetic acid induced writhings. Therefore the extracts derived from rhizomes of alpinia galanga might be inhibiting synthesis or release of these endogenous substances. It is suggested that cyclooxygenase and lipoxygenase pathway of the arachidonate cascade are blocked by flavonoids at high concentration, while at low concentration only lipoxygenase pathway is blocked. ${ }^{28}$ Flavonoids produces analgesic action by opioid like action. ${ }^{29}$ Furthermore, there are few reports suggesting the role of tannins in analgesic activity. ${ }^{30}$ Studies suggest that alkaloids also involve in analgesic action through non-narcotic action. ${ }^{31,32}$ In the present study phytoconstituents such as flavonoids, tannins and alkaloids might be attributed to the central and peripheral analgesic activities of EEAGR.

\section{Conclusion}

The study concludes that EEAGR possess central and peripheral analgesic activity in experimental animals. The present findings justify that Alpinia galanga can be used as a natural source for alternative therapeutic drug for the treatment of various painful conditions. Further pharmacological analysis of the Alpinia galanga rhizome extract is needed to isolate and characterize the active ingredients and its molecular level mode of action responsible for these effects.

\section{Acknowledgements}

Further, the authors wish to extend their gratitude to the anonymous reviewers for their valuable comments in improvising the research.

Funding: No funding sources

\section{Conflict of Interest: None.}

Ethical Approval: Approved by the Institutional Animal Ethics Committee.

\section{References}

1. Kumar V, Abbas AK, Aster JC. Robbins Basic Pathology. Inflammation and Repair. 9th ed. Elsevier Saunders; Philadelphia: 2015.p.29- 58.

2. Barrett KE, Barman SM, Boitano S, Brooks HL. Ganong's review of Medical physiology. Pain \& Temperature. $23^{\text {rd }}$ ed. Tata McGraw Hill Education Private Limited; New Delhi: 2010.p.167.

3. Ong CKS, Lirk P, Tan CH, Seymour RA. An Evidence-Based Update on Non-steroidal anti-inflammatory drugs. Clin Med Res. 2007;5,19-34.

4. Li RW, Mayers SP, Leach DN, Lin GD, Leach G. A cross cultural study: Anti-inflammatory activity of Australian and Chinese plants. J Ethnopharmacol. 2003;85:25-32.

5. Duffy JC, Dearden JC, Rostron C. Design, synthesis and biological testing of a novel series of anti-inflammatory drugs. J Pharm Pharmacol. 2001;53:1505-1514.

6. Zakaria M, Mustafa AM. Traditional Malay Medical Plants. Fajar Bakti; Kuala Lumpur: 1994.

7. Calixto JB. Twenty-five years of research on medicinal plants in Latin America: a personal view. J Ethnopharmacol. 2005;100:131-134.

8. Kaushik D, Yadav J, Kaushik P, Sacher D and Rani R. “ Current pharmacological and phytochemical studies of the plant Alpinia galangal" J Chin Integr Med. 2011;10,10611065.

9. Chen IN, Chang CC, Ng CC, Wang CY, Shyu YT and Chang TL. "Antioxidant and antimicrobial activity of Zingiberaceae plants in Taiwan. Plant Foods for Human Nutrition. 2008;63:15-20.

10. Chourasiya SS, Sreedhar E, Babu KS, Shankaraiah N, Nayak VL, Ramakrishna $\mathrm{S}$ et al. Isolation, synthesis and biological evaluation of phenylpropanoids from the rhizomes of Alpinia galangal. Nat Prod Commun. 2013;12:1741-1746.

11. Bian MQ, Kang J, Wang HQ, Zhang QJ, Liu C and Chen RY. "Three new norsesquiterpenoids from the seeds of Alpinia galangal. J Asian Nat Prod Res. 2014;16,459-464.

12. Samarghandian S, Hadjzadeh MA, Afshari JT and Hosseini M. Antiproliferative activity and induction of apoptotic by ethanolic extract of Alpinia galanga rhizome in human breast carcinoma cell line. BMC Complement Altern Med. 2014;14:192.

13. Saha $\mathrm{S}$ and Banerjee $\mathrm{S}$. Central nervous system stimulant actions of Alpinia galanga (L.) rhizome: a preliminary study. Indian J Exp Biol. 2013;10:828-832.

14. Erturk O. "Antibacterial and antifungal activity of ethanolic extract from eleven spice plants. Biologia Bratislava. 2006;61:275-278.

15. Barnes J. "Trease and Evans' Pharmacognosy" Focus on Alternative and Complementary Therapies. 1999;4:151-152.

16. Harborne JB. Phytochemical methods: a guide to modern techniques of plant analysis. $3^{\text {rd }}$ ed. Chapman \& Hall; London: 1998. p.302.

17. Subash KR, Muthulakshmi Bhaarathi G, Jagan Rao N, Binoy Vargeese Cheriyan. Phytochemical screening and acute toxicity study of ethanolic extract of alpinia galangal in rodents. Int J Medi Res Health Sci. 2013;2:93-100.

18. Panthong A, Norkaew P, Kanjanapothi D, Taesotikul T, Anantachoke N, Reutrakul V. Anti-inflammatory, analgesic and antipyretic activities of extract of gamboges from Garcina hanburyi Hook f. J Ethnopharmacol. 2007;111:335-340. 
19. Indumathy S, Kavimani S. Analgesic activity of angiotensin antagonists. Afr J Pharm Pharmacol. 2011;5(2):194-198.

20. Rajveer CH, Swarnalatha CH, Rathinaraj BS, Sudharshini S. "Synthesis of 6-Bromooxo quinazoline derivatives and their pharmacological activities. Int J Chemi Res. 2010;1:21-24.

21. Sharma US, Sharma UK, Sutar N, Ahmed S, Kulshreshtha PK. Evaluation of analgesic, anti-pyretic and anti inflammatory activities of Andropogan Muricatus root extract. J Pharm Res. 2010;3:1652-1654.

22. Sharma PK, Singh V, Md. Ali and Kumar S. "Evaluation of Antinociceptive and Antiinflammatory Activities of Methanolic Extract of Alpinia Galanga Rhizomes in Animal Models. Int J Pharm Sci Res. 2015;6:3103-3108.

23. Acharya SD, Ullal SD, Padiyar S, Rao YD, Upadhyaya K, Pillai D, Raj V. "Analgesic effect of extracts of Alpinia galanga rhizomes in mice" J Chin Integr Med. 2011;9:100104.

24. Schumacher GA, Goodell H, Hardy JD, Wolff HG.

"Uniformity of the pain threshold in man. Sci. 1940;92:110112.

25. Medhi B, Prakash A. Commonly used instruments in Pharmacology laboratory. Practical Manual of Experimental and Clinical Pharmacology. 1st ed. Jaypee; Chandigarh: 2010. p.76-81.

26. Mishra D, Ghosh G, Kumar PS, Panda PK. An experimental study of analgesic activity of selective COX-2 inhibitor with conventional NSAIDs. Asian J Pharm Clin Res. 2011;4:78-81.

27. Koster R, Anderson M, De Beer EJ. Acetic acid for analgesic screening. Federation Proceedings. 1959;18:412-417.
28. Pourmotabbed A, Farshchi A, Ghiasi G, Khatabi PM. Analgesic and anti-inflammatory activity of Teucrium chamaedrys leaves aqueous extract in male rats. Irani $J$ Basic Med Sci. 2010;13;119-125.

29. Thirugnanasambantham P, Viswanathan S, Mythirayee C, Krishnamurty V, Ramachandran S, Kameswaran L. "Analgesic activity of certain flavone derivatives: a structure-activity study. J Ethnopharmacol. 1990;28:207-214.

30. Chakraborty A, Devi RK, Rita S, Sharatchandra K, Singh TI. Preliminary studies on anti-inflammatory and analgesic activities of Spilanthes acmella in experimental animal models. Indian J Pharmacol. 2004;36,148-150.

31. Goji AD. A study of the anti-inflammatory and analgesic activities of aqueous extract of Nauclea latifolia leaves in rodents. Asian J Med Sci. 2010;2:244-247.

32. Farouk L, Laroubi A, Aboufatima R, Benharref A, Chait A. Evaluation of the analgesic effect of alkaloid extract of Peganum harmala L.: possible mechanisms involved. $J$ Ethnopharmacol. 2008;115:449-454.

How to cite this article: Sriraj D, Rauf $M$. A. Evaluation of analgesic activity of ethanolic extract of alpinia galanga rhizomes in experimental animal models. Indian J Pharm Pharmacol. 2018;5(4):164-169. 